\title{
Prolactin enhances the in vitro production of IgG in peripheral blood mononuclear cells from patients with systemic lupus erythematosus but not from healthy controls
}

\author{
A M Jacobi, W Rohde, H-D Volk, T Dörner, G-R Burmester, F Hiepe
}

Department of Medicine, Charité University Hospitals Berlin, Germany A $M$ Jacobi

T Dörner

G-R Burmester

F Hiepe

Institute of

Experimental

Endocrinology, Charité University

Hospitals Berlin,

Germany

W Rohde

Institute of Medical Immunology, Charité University Hospitals Berlin, Germany H-D Volk

Correspondence to: Professor Dr med F Hiepe, Medizinische Klinik mit Schwerpunkt,

Rheumatologie und Klinische Immunologie,

Universitätsklinikum Charité,

Humboldt-Universität, Schumannstr $20 / 21$, D-10117 Berlin, Germany falk.hiepe@charité.de

Accepted 28 July 2000

\begin{abstract}
Objectives-Recent evidence suggests that prolactin (PRL) plays a part in the pathogenesis of systemic lupus erythematosus (SLE). Because B cell hyperreactivity and autoantibodies are characteristic hallmarks of SLE, this study aimed at assessing the impact of this pituitary hormone on IgG production by stimulating peripheral blood mononuclear cells (PBMC) with PRL.
\end{abstract}

Methods-PBMC from 11 patients with SLE assessed by the ECLAM score and eight healthy controls were incubated with PRL and cultured for seven days. IgG production was measured by enzyme linked immunosorbent assay (ELISA).

Results-Spontaneous IgG production of SLE PBMC was significantly enhanced compared with that found in healthy controls. After PRL stimulation, the IgG concentrations of supernatants from SLE PBMC were significantly higher than those of unstimulated PBMC (median 394 $\mathrm{ng} / \mathrm{ml}$ ). Of note, the physiological concentration of PRL $(20 \mathrm{ng} / \mathrm{ml})$ induced IgG production more effectively (median 1139 $\mathrm{ng} / \mathrm{ml}$ ) than PRL at $100 \mathrm{ng} / \mathrm{ml}$ (median $1029 \mathrm{ng} / \mathrm{ml}$ ). In contrast, preincubation with PRL did not stimulate IgG production in normal PBMC. A significant correlation between PRL induced IgG production and the disease activity (ECLAM) of the patients with SLE was seen. Moreover, the maximum amount of PRL induced IgG depended on the serum PRL concentrations of the patients with SLE.

Conclusions-The results suggest that PBMC from patients with SLE have an extraordinarily high susceptibility to PRL, showing the most striking effect at a concentration usually found in vivo. This indicates a potential role for mild hyperprolactinaemia in the pathogenesis of SLE, influencing both IgG production and disease activity.

(Ann Rheum Dis 2001;60:242-247)

Prolactin (PRL) is a polypeptide hormone with a heterogeneous function and is produced by a variety of tissues in the human body. Besides its production in the pituitary gland, many cells of the immune system can synthesise PRL and respond to PRL transmitted signals with the help of specific PRL receptors using different signal transduction pathways. PRL functions similarly to a cytokine, though it acts not only in an endocrine but also in a paracrine and autocrine manner. ${ }^{1}$ PRL is also known to stimulate the humoral and cellular immune response..$^{2-6}$ Thus it has been shown to stimulate the immunoglobulin and autoantibody production of human peripheral blood mononuclear cells (PBMC) from healthy subjects and patients with systemic lupus erythematosus (SLE). ${ }^{2}$ On the other hand, PRL is secreted by PBMC from healthy subjects and in even larger amounts by PBMC from patients with SLE. ${ }^{7}$ Animal models resembling SLE show a correlation between the PRL levels and disease activity. ${ }^{89}$ These studies indicate that PRL may play a part in the pathogenesis of SLE. Furthermore, other studies have reported an increased prevalence of various autoantibodies in patients with hyperprolactinaemia, ${ }^{10-12}$ and others found raised PRL levels in patients with autoimmune diseases, ${ }^{13-29}$ most notably, in patients with SLE at a prevalence of $2-31 \%$. However, these studies gave contradictory results for the correlation between PRL levels and the clinical or serological disease activity. Furthermore, it has also been shown that reduction of the PRL level in SLE by bromocriptine, a dopamine agonist, decreases the frequency of lupus flares in patients with SLE and reduces overall disease activity. ${ }^{30}{ }^{31}$ Because previous studies provided inconclusive evidence about the influence of serum PRL on disease activity and serological abnormalities in SLE, this study determined the influence of PRL at two different concentrations - namely, 20 and $100 \mathrm{ng} /$ $\mathrm{ml}$, on the IgG secretion of PBMC from patients with SLE and healthy controls in vitro to estimate the impact of hyperprolactinaemia on the disease activity. Of note, previous studies showed that up to $31 \%$ of patients with SLE have PRL levels between 20 and $100 \mathrm{ng} / \mathrm{ml}$.

\section{Methods}

PATIENTS AND HEALTHY CONTROLS

The study included 11 patients (eight female, three male) who fulfilled the American College of Rheumatology criteria for $\mathrm{SLE}^{32}$ and eight healthy subjects (six female, two male, blood 
Table 1 Characteristics of the patients with systemic lupus erythematosus analysed, clinical manifestations of the disease and other signs of disease activity underlying the ECLAM score

\begin{tabular}{|c|c|c|c|c|c|c|c|c|c|c|c|c|c|c|c|c|c|}
\hline Patient & Age (y) & Sex & $\begin{array}{l}P R L^{\star} \\
(\mathrm{ng} / \mathrm{ml})\end{array}$ & $\begin{array}{l}\text { ECLAM } \\
\text { score }\end{array}$ & $A N A^{*}+$ & $E N A^{\star}$ & $\begin{array}{l}a C L \\
\operatorname{Ig} G^{\star}\end{array}$ & $\begin{array}{l}a D N A \\
\operatorname{Ig} G^{\star}\end{array}$ & $C L-I F^{\star}+$ & $\begin{array}{l}\text { Raised } \\
\text { ESR }^{\star}\end{array}$ & $\begin{array}{l}\text { Decrease } \\
\text { of } C 3 / C 4\end{array}$ & $\begin{array}{l}\text { Fever/ } \\
\text { fatigue }\end{array}$ & Skin & foint & Haematological & Kidney & $C N S^{*}$ \\
\hline 1 & 21 & M & 6.4 & 3 & 2560 & $\mathrm{Ro} / \mathrm{La} / \mathrm{Sm}$ & ++ & 129.7 & 16 & - & - & + & + & - & - & + & - \\
\hline 2 & 40 & M & 10.1 & 7 & 160 & $\mathrm{Ro} / \mathrm{La} / \mathrm{Sm}$ & ++ & 80 & 32 & + & + & + & + & + & + & + & - \\
\hline 3 & 57 & $\mathrm{~F}$ & 10.8 & 4 & 1280 & $\mathrm{Ro} / \mathrm{La}$ & + & 11.6 & - & - & - & + & + & - & + & - & + \\
\hline 4 & 30 & $\mathrm{~F}$ & 34.3 & 10 & 640 & $\mathrm{La}$ & ++ & 225 & 128 & + & + & + & + & + & + & + & + \\
\hline 5 & 21 & M & 20.5 & 4 & 1280 & $\mathrm{Ro} / \mathrm{La} / \mathrm{Sm}$ & ++ & 34.2 & 32 & - & + & - & - & - & + & + & - \\
\hline 6 & 39 & $\mathrm{~F}$ & 21.2 & 5 & 320 & $\mathrm{Ro} / \mathrm{La}$ & - & - & - & + & - & + & + & - & + & + & - \\
\hline 7 & 21 & $\mathrm{~F}$ & 24.7 & 4 & 1280 & $\mathrm{Ro} / \mathrm{La}$ & + & - & - & + & + & - & + & - & - & + & - \\
\hline 8 & 48 & $\mathrm{~F}$ & 19.8 & 10 & 10240 & Ro & ++ & 140 & 128 & + & + & + & + & + & + & - & - \\
\hline 9 & 17 & $\mathrm{~F}$ & 39.5 & 3 & 640 & - & - & 16 & 2 & + & + & - & - & - & - & + & - \\
\hline 10 & 30 & $\mathrm{~F}$ & 9.5 & 1 & 320 & - & + & 21.1 & - & + & - & - & - & - & - & - & - \\
\hline 11 & 25 & $\mathrm{~F}$ & 15.4 & 6 & 1280 & $\mathrm{Ro} / \mathrm{La}$ & + & 26.3 & - & - & + & - & + & + & - & + & - \\
\hline
\end{tabular}

$\star \mathrm{PRL}=$ prolactin; ANA $=$ antinuclear antibodies; ENA $=$ extactable nuclear antigens; $\mathrm{aCL}=$ anticardiolipin antibodies, positive $(+)>50 \mathrm{U} / \mathrm{ml},++>100 \mathrm{U} / \mathrm{ml}$; aDNA $=$ anti-dsDNA ELISA, positive $\geqslant 6 \mathrm{AU}$; CL-IF = anti-dsDNA antibodies determined by Crithidia luciliae immunofluorescence technique; ESR = erythrocyte sedimentation rate; $\mathrm{CNS}=$ central nervous system.

†Reciprocal titre, + means positive or present; - means negative or not present.

donors). The patients with SLE were aged 17-57 years (median 30) and controls were aged 19-54 (median 30.5). The disease activity of patients with SLE was analysed according to the European Consensus Lupus Activity Measurement score (ECLAM score), ${ }^{33}$ assessing clinical as well as serological findings (table 1).

Venous blood was taken for the detection of serum concentrations of PRL. At the same time, citrate blood $(40 \mathrm{ml})$ was obtained for preparation of the PBMC cultures. Patients who had obvious causes for hyperprolactinaemia - for example, pregnancy, prolactinoma, hypothyroidism, advanced renal insufficiency (creatinine $>180 \mu \mathrm{mol} / \mathrm{l}$ ), or patients receiving drugs with a side effect of increase in PRL, were excluded from the study. Six patients were receiving treatment with intravenous cyclophosphamide and prednisone, three were receiving methylprednisolone bolus treatment, and one patient was receiving azathioprine alone. Another patient did not receive any immunosuppressive treatment at the time of the study. None of these immunosuppressive drugs influence the serum PRL concentration.

MEASUREMENT OF SERUM LEVELS OF PRL

All blood samples were obtained with minimal trauma by venepuncture of the cubital vein between $900 \mathrm{am}$ and $1200 \mathrm{am}$, with a previous period of fasting and resting. Serum was separated and stored at $-20^{\circ} \mathrm{C}$ until the hormonal assay was performed. Serum PRL was determined by enzyme linked immunosorbent assay (ELISA, Elias-Medizintechnik $\mathrm{GmbH}$, Freiburg, Germany). The cut off serum PRL concentration for the assay was $15 \mathrm{ng} / \mathrm{ml}$ for male and $20 \mathrm{ng} / \mathrm{ml}$ for female subjects. PRL levels were not determined in the buffy coats of healthy blood donors because of technical reasons.

\section{CELL CULTURES}

PBMC were isolated from citrate blood samples by Ficoll-Hypaque separation according to standard protocols ${ }^{34}$ (Seromed, Berlin, Germany), including three washing steps with phosphate buffered saline (PBS, $\mathrm{pH}$ 7.4; Seromed). The PBMC $\left(1 \times 10^{6}\right.$ cells $\left./ \mathrm{ml}\right)$ were resuspended in medium (RPMI 1640,
Seromed) containing $5 \%$ fetal calf serum (Seromed), streptomycin/penicillin $(10 \mathrm{U} / \mathrm{ml}$, Seromed), and r-PRL (20 and $100 \mathrm{ng} / \mathrm{ml}$ ) (Genzyme Corporation, Cambridge, USA). Subsequently, the cells were cultured in a $\mathrm{CO}_{2}$ incubator $\left(5 \% \mathrm{CO}_{2}\right)$ at $37^{\circ} \mathrm{C}$ for seven days. Thereafter, cell culture supernatants were collected and stored at $-20^{\circ} \mathrm{C}$ until measurement of the IgG concentration.

In further control experiments, lipopolysaccharide (LPS; Sigma, Berlin, Germany) was added to the PBMC cultures of 3/11 patients and of two healthy controls to assess an endotoxin related effect of the PRL on the IgG production of PBMC. The endotoxin concentration of PRL used was $0.02 \mathrm{ng} / \mu \mathrm{g}$, according to the product information given by the supplier (Genzyme Corporation). To estimate the potential effect of the LPS contained in the r-PRL in more detail, PBMC were also incubated with the endotoxin LPS $(2 \mathrm{pg} / \mathrm{ml})$ at a concentration comparable with that expected in a solution of medium containing PRL at 100 $\mathrm{ng} / \mathrm{ml}$. In addition, LPS was also added at a concentration of $10 \mathrm{pg} / \mathrm{ml}$.

DETERMINATION OF THE IgG CONCENTRATION IN THE CULTURE SUPERNATANTS

The IgG concentration of the supernatants was determined by a one step enzyme immunoassay, "Human IgG SURALISA" (Seramun Diagnostika GmbH, Dolgenbrot, Germany) using a sheep high affinity polyclonal IgG antibody.

Statistical analysis was performed with GraphPad Prism 2.01 for Windows 95. The median IgG concentration of the cell culture supernatants and the median PRL level and disease activity of the patients with SLE were analysed. The Mann-Whitney U test was used to compare the IgG concentrations of the cell culture supernatants of patients with SLE and those of healthy controls. Subsequently, the effect of PRL on the IgG production of SLE PBMC was assessed by comparing the IgG concentrations before and after incubation with PRL using the non-parametric Wilcoxon test with Bonferroni correction. In addition, the correlation of IgG production with disease activity in SLE was assessed by Spearman's rank correlation test. 


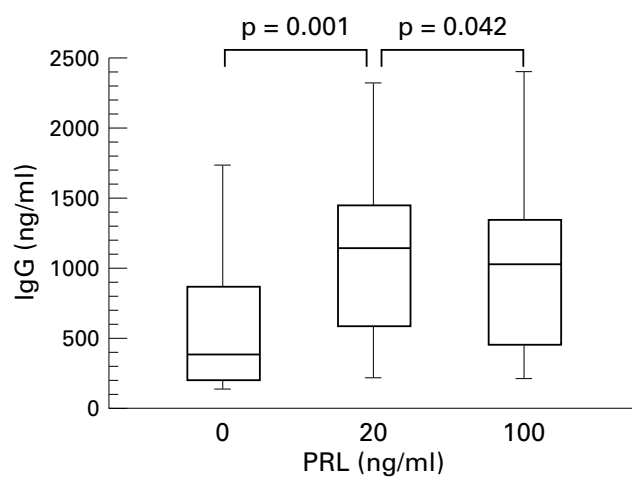

Figure 1 Concentration of total IgG in the supernatants of peripheral blood mononuclear cells (PBMC) obtained from 11 patients with systemic lupus erythematosus (SLE) after incubation with prolactin (PRL) at concentrations of 20 and $100 \mathrm{ng} / \mathrm{ml}$, respectively, and without PRL (0) for seven days. Significant differences were seen between the IgG production by PBMC from patients with SLE after and without stimulation with PRL (20 and $100 \mathrm{ng} / \mathrm{ml}$, respectively) (Wilcoxon test and Bonferroni correction, $p=0.043)$.

\section{Results}

Serum PRL concentrations were raised in six patients with SLE, while five had normal levels. Table 1 shows characteristics and serum PRL concentrations of the patients with SLE studied.

SPONTANEOUS IgG PRODUCTION IN PBMC CULTURES

The IgG concentration was significantly higher in cell culture supernatants of PBMC from patients with SLE (median $394 \mathrm{ng} / \mathrm{ml}$, range 132-1734) than in supernatants of PBMC from healthy controls where the IgG concentrations were below the detectable concentration of the assay used $(<150 \mathrm{ng} / \mathrm{ml})(\mathrm{p}<0.0001$, Mann-Whitney U test).

INFLUENCE OF PRL ON IgG PRODUCTION

After incubation with PRL at an overall physiological concentration $(20 \mathrm{ng} / \mathrm{ml})$, a remarkable increase in the IgG production of SLE PBMC was detected (fig 1). The IgG concentration was significantly higher (median 1139 $\mathrm{ng} / \mathrm{ml}$, range 223-2316) than that determined for PBMC without stimulation ( $p=0.001$, Wilcoxon test).

The IgG concentrations of the supernatants of PBMC from patients with SLE after incubation with PRL at a concentration of 100 $\mathrm{ng} / \mathrm{ml}$ were also significantly higher (median value $1029 \mathrm{ng} / \mathrm{ml}$, range 215-2390) than the basal concentration of IgG ( $p=0.002$, Wilcoxon test). Most notably, the increase in IgG production was significantly lower than that seen after incubation with PRL at the physiological concentration of $20 \mathrm{ng} / \mathrm{ml}$ (Wilcoxon test and Bonferroni correction $\mathrm{p}=0.043$ ).

In contrast, such an increase in IgG production was not detected in the PBMC obtained from healthy controls either after incubation with PRL at the physiological $(20 \mathrm{ng} / \mathrm{ml})$ or at the high $(100 \mathrm{ng} / \mathrm{ml})$ concentration with values below $150 \mathrm{ng} \mathrm{IgG} / \mathrm{ml}$. However, in one of the eight blood donors a mild increase in the IgG concentration after incubation with PRL was detected (spontaneous $<150 \mathrm{ng} / \mathrm{ml} v \mathrm{PRL}$ at $20 \mathrm{ng} / \mathrm{ml}: 272 \mathrm{ng} / \mathrm{ml}$ and $v$ PRL at $100 \mathrm{ng} / \mathrm{ml}$ : $264 \mathrm{ng} / \mathrm{ml})$.

INFLUENCE OF LPS ON IgG PRODUCTION

To exclude the possibility that the observed PRL effect on IgG production is related to an endotoxin contamination of the PRL used, we examined the impact of two LPS concentrations (2 and $10 \mathrm{pg} / \mathrm{ml}$ ) on IgG production in the PBMC of three patients with SLE and two healthy controls. LPS at a concentration of 2 $\mathrm{pg} / \mathrm{ml}$ did not alter the IgG production of PBMC from patients with SLE (spontaneous $508 \mathrm{ng} / \mathrm{ml} v$ LPS at $2 \mathrm{pg} / \mathrm{ml}: 515 \mathrm{ng} / \mathrm{ml}$, mean values), whereas LPS at a higher concentration $(10 \mathrm{pg} / \mathrm{ml})$ caused a mild increase of the IgG production (mean value $645 \mathrm{ng} / \mathrm{ml}$ ). However, this difference was not statistically significant (Wilcoxon test) and markedly less than that induced by PRL, especially at a concentration of $20 \mathrm{ng} / \mathrm{ml}$. Moreover, no increase in the IgG production of PBMC from two healthy subjects was seen after incubation with LPS at either of the concentrations ( 2 and $10 \mathrm{pg} / \mathrm{ml}$ ).

CORRELATION OF IgG PRODUCTION IN CELL CULTURE SUPERNATANTS OF PBMC FROM PATIENTS WITH SLE AND THE DISEASE ACTIVITY Further analysis of the spontaneous production of IgG by PBMC and the disease activity of the patients with SLE did not show a significant correlation $\left(r_{\mathrm{s}}=0.5208, \mathrm{p}=0.1003\right.$, Spearman's rank correlation). However, the IgG concentrations after incubation with PRL at a
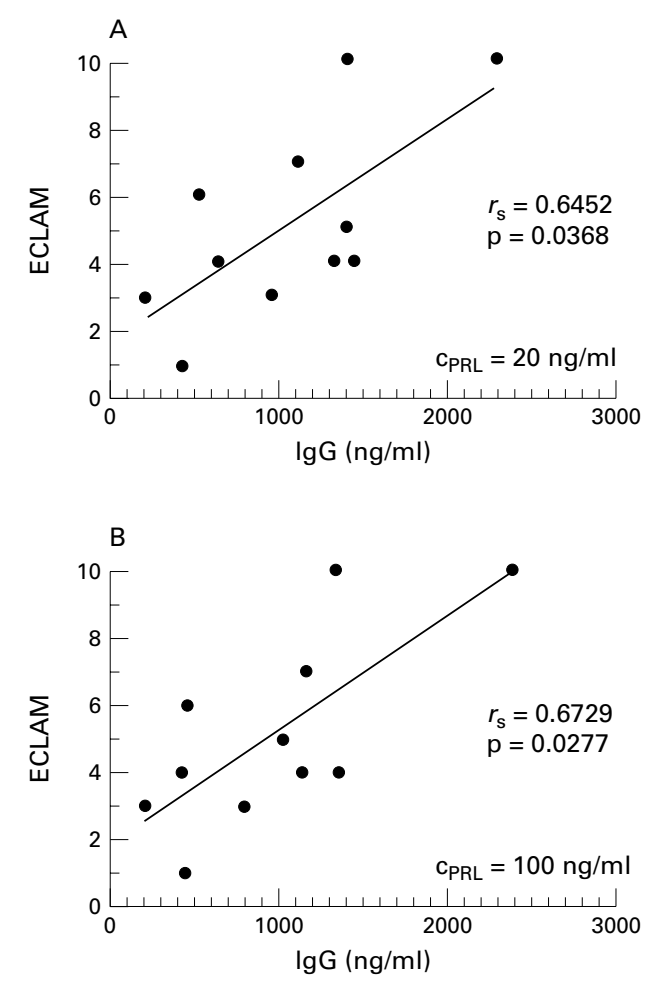

Figure 2 Correlation of the IgG concentration of the supernatants of peripheral blood mononuclear cells from patients with systemic lupus erythematosus (SLE) after incubation with prolactin (PRL) at two concentrations $\left(C_{P R L}=20 \mathrm{ng} / \mathrm{ml}\right.$ and $\left.100 \mathrm{ng} / \mathrm{ml}\right)$ and the ECLAM score of the patients with SLE analysed. 
concentration of $20 \mathrm{ng} / \mathrm{ml}$ and $100 \mathrm{ng} / \mathrm{ml}$, respectively, did correlate with the disease activity of the patients with SLE analysed $\left(r_{\mathrm{s}}=0.6452, \quad \mathrm{p}=0.0368\right.$ and $r_{\mathrm{s}}=0.6729$; $\mathrm{p}=0.0277$, respectively) (fig 2 ). These data indicate that there is a strong correlation between the ECLAM score and IgG production after, but not without, stimulation with PRL at various concentrations.

CORRELATION OF IgG PRODUCTION IN CELL CULTURE SUPERNATANTS OF PBMC FROM

PATIENTS WITH SLE AND THE PRL SERUM LEVEL

When the PRL serum levels of the patients with SLE were considered, a difference in IgG production between the groups with normal and raised serum PRL was found which was not statistically significant. The IgG concentrations were higher in cell culture supernatants of hyperprolactinaemic patients with SLE regardless of the concentration of incubated PRL, though the differences were not significant $\left(\mathrm{p}=0.0536 \quad\left(\mathrm{C}_{\mathrm{PRL}}=20 \mathrm{ng} / \mathrm{ml}\right)\right.$ and $\mathrm{p}=0.2468$ $\left(\mathrm{C}_{\mathrm{PRL}}=100 \mathrm{ng} / \mathrm{ml}\right.$; Mann-Whitney U test) because of the small number of patients analysed.

\section{Discussion}

This study analysed the influence of PRL on in vitro IgG production and its relation to disease activity in patients with SLE.

Overall, the spontaneous IgG production of PBMC from patients with SLE did not depend on the disease activity and serum PRL levels of the patients examined.

To our knowledge this is the first study analysing the effect of PRL at a concentration of 20 $\mathrm{ng} / \mathrm{ml}$, equivalent to the median serum PRL concentration of these patients, on the IgG production of their PBMC which shows a significant enhancement. This effect was also shown for PRL at a higher concentration (100 $\mathrm{ng} / \mathrm{ml})$, though the impact on IgG production was less. Remarkably, PRL exerts a greater effect on IgG production at its overall physiological concentration than at $100 \mathrm{ng} / \mathrm{ml}$. This supports the theory of the dimerisation model, which has been suggested not only for the growth hormone receptor ${ }^{35}$ but also for the PRL receptor. ${ }^{36}$ At high ligand concentrations, receptor dimerisation is blocked because two PRL molecules are bound to one receptor, whereas binding of one molecule/receptor is seen at low ligand concentration.

Most notably, the correlation of in vitro IgG production of PBMC from patients with SLE caused by incubation with PRL and the disease activity indicates that the susceptibility to PRL is markedly related to the disease activity. PBMC of patients with active disease had a high susceptibility to PRL, with a more marked increase in IgG production than PBMC from patients with low disease activity. After incubation with PRL, and spontaneously, PBMC from healthy controls did not produce detectable amounts of $\mathrm{IgG}$, providing a striking difference from the patients with SLE. The current results provide evidence that the influence of PRL on IgG production depends on the disease activity, whereas PRL does not increase the IgG production of PBMC obtained from normal controls. This is consistent with the observation of Lahat et al, who found that PRL at a concentration of $0.2-100 \mathrm{ng} / \mathrm{ml}$ affected the immunoglobulin production of anti-IgM stimulated or interleukin 2 (IL2) stimulated B cells from healthy subjects but did not affect unstimulated cells. ${ }^{3}$ Preactivation of the cells seems to be required for the PRL dependent enhancement of IgG production. In contrast, Gutiérrez et al showed that PRL enhances the immunoglobulin production of PBMC from healthy subjects more strikingly than from PBMC of patients with SLE. ${ }^{2}$ This difference might be accounted for by the higher PRL concentration used, far exceeding the physiological range of serum PRL levels in healthy subjects.

The results of our study indicate that the significantly increased production of IgG by PBMC from patients with SLE cannot be ascribed to PRL alone. Thus the PBMC from the patients with SLE produced high amounts of IgG spontaneously that could be further enhanced by incubation with PRL. In general, there must be a regulatory defect of $\mathrm{B}$ cells in SLE, or of the interaction of the PBMC from patients with SLE, causing a more or less unregulated production of immunoglobulin and, probably, autoantibodies. Obviously, PRL can enhance this immunoglobulin production in vitro, though it is not uniquely responsible for the induction of immunoglobulin or autoantibody production at PRL concentrations between 20 and $100 \mathrm{ng} / \mathrm{ml}$. The lack of enhanced immunoglobulin production by PBMC from normal donors after incubation with PRL suggests that either preactivation by the disease or inherited cellular defects account for the observed abnormalities of the immunoglobulin production by PBMC from patients with SLE. Alternatively, PRL could potentially permit a more efficient maturation of $B$ cells into antibody producing plasma cells. Although further proof is needed, the induction of IL2 receptors by PRL, as previously shown in rat splenocytes, ${ }^{37}$ can increase the generation of antibody producing cells as IL2 is known to permit the maturation of plasma cells. ${ }^{38}$

If these in vitro results are transferable to an in vivo situation, patients with SLE with mild hyperprolactinaemia, representing up to one third of all patients with SLE (unpublished data), provide conditions for an enhanced immunoglobulin production and autoantibody generation. Although somewhat speculative, this might explain the positive therapeutic effect of bromocriptine in normoprolactinaemic patients, as described previously, ${ }^{30}{ }^{31}$ and the frequently observed exacerbation of SLE during pregnancy.

The impact of PRL on IgG production in vitro seemed to depend on the disease activity. Therefore, the data suggest that the extent of PRL induced enhancement of the (auto)antibody production in SLE is correlated with the disease activity in vivo. To what extent PRL itself is responsible for an increase in disease activity and its origin in patients with SLE remains uncertain. However, the results 
suggest that low serum PRL levels indicate a low risk of disease exacerbation.

One explanation for the observed difference in the susceptibility of PBMC from patients with SLE and normal controls to PRL in vitro might be that SLE PBMC express a high number of PRL receptors by prior activation in vivo. Alternatively, they may, like CLL-B cells, ${ }^{39}$ have the ability to receive additional signals transmitted by high molecular weight PRL by specific mechanisms of receptor function or of intracellular signal transduction. High molecular weight PRL consists of PRL bound to an anti-PRL antibody (IgG) $)^{40}$ and has been reported to occur frequently in patients with SLE. ${ }^{41}$ Furthermore, it has been postulated to be a cause of raised PRL levels in patients with SLE owing to the reduced clearance of the macromolecule or its impaired penetration to the hypothalamus and a subsequent disturbance of the hypothalamic pituitary feedback mechanism. Another possible explanation is the influence of PRL on the apoptosis of (auto)antibody producing B cells. It has been shown that PRL increases the expression of anti-apoptotic proteins, such as bcl-2 or bax, in Nb2 lymphoma cells. ${ }^{42}$ PRL has also been shown to prevent these cells from glucocorticoid induced apoptosis, ${ }^{43}$ raising the question, whether slightly raised serum PRL levels in patients with SLE decrease the therapeutic effect of steroid treatment.

The results of the current study suggest an impact of mild hyperprolactinaemia on the immunoglobulin production and disease activity in SLE. As far as we know, no data have been published about the effect of PRL at an overall physiological concentration on PBMC from patients with SLE that indicate a potential role for borderline serum PRL or mild hyperprolactinaemia in aggravating or perpetuating the disease. However, this impact of PRL is strongly related to the disease activity of the patients and probably related to an increased susceptibility of PBMC to PRL in patients with disease flares. In further studies our attention needs to be focused more on the detailed mechanisms underlying the increased IgG response to PRL in SLE PBMC than on the question whether there are increased levels of serum PRL in SLE.

This study was supported by a grant from the Deutsche Forschungsgemeinschaft (Hi 620/1-1, SFB 421, C4).

1 Ben Jonathan N, Mershon JL, Allen DL, Steinmetz RW. Extrapituitary prolactin: distribution, regulation, functions, Extrapituitary prolactin: distribution, regulation, func

2 Gutiérrez MA, Molina JF, Jara LJ, Garcia C, GutiérrezUrena S, Cuellar ML, et al. Prolactin-induced immunoglobulin and autoantibody production by peripheral blood mononuclear cells from systemic lupus erythematosus and normal individuals. Int Arch Allergy Immunol 1996;109: 229-35.

3 Lahat N, Miller A, Shtiller R, Touby E. Differential effects of prolactin upon activation and differentiation of human $\mathrm{B}$ lymphocytes. J Neuroimmunol 1993;47:35-40.

4 Nagy E, Berczi I, Friesen HG. Regulation of immunity in rats by lactogenic and growth hormones. Acta Endocrinologica (Copenhagen) 1983;102:351-7.

5 Berczi I, Nagy E, Asa SL, Kovacs K. Pituitary hormones

6 Nagy E, Berczi I, Wren GE, Asa SL, Kovacs K. Immunomodulation by bromocriptine. ImmunopharmaImmunomodulation by

7 Gutiérrez MA, Molina JF, Jara LJ, Cuellar ML, Garcia C, Gutiérrez-Urena S, et al. Prolactin and systemic lupus erythematosus: prolactin secretion by SLE lymphocytes and proliferative (autocrine) activity Lupus 1995;4:34852 .

8 Elbourne KB, Keisler D, McMurray RW. Differential effects of estrogen and prolactin on autoimmune disease in the NZB/NZW F1 mouse model of systemic lupus erythematosus. Lupus 1998;7:420-7.

9 McMurray R, Keisler D, Kanuckel K, Izui S, Walker SE. Prolactin influences autoimmune disease activity in the female B/W mouse. J Immunol 1991;147:3780-7.

10 Buskila D, Berezin M, Gur H, Lin HC, Alosachie I, Terryberry JW, et al. Autoantibody profile in the sera of women with hyperprolactinemia. J Autoimmun 1995;8:415-24.

11 Ferrari C, Boghen M, Paracchi A, Rampini P, Raiteri F, Benco $R$, et al. Thyroid autoimmunity in hyperprolactinaemic disorders. Acta Endocrinolologica (Copenhagen) 1983;104:35-41.

12 Krause I, Blumenfeld Z, Malchinsky M, Cohen S, Blank M, Eldor A, et al. Anti-endothelial cell antibodies in the sera of hyperprolactinemic women. Lupus 1998;7:377-82.

13 Hedner LP, Bynke G. Endogenous iridocyclitis relieved during treatment with bromocriptine. Am J Ophthalmol 1985;100:618-19

14 Lever EG, McKerron CG. Auto-immune Addison's disease associated with hyperprolactinaemia. Clin Endocrinol (Oxf) 1984;21:451-7.

15 Honegger J, Fahlbusch R, Bornemann A, Hensen J, Buchfelder M, Muller M, et al. Lymphocytic and granulomatous hypophysitis: experience with nine cases. Neurosurgery 1997;40:713-22.

16 Gutiérrez MA, Anaya JM, Scopelitis E, Citera G, Silveira L, Espinoza LR. Hyperprolactinaemia in primary Sjögren's syndrome. Ann Rheum Dis 1994;53:425.

17 Kucharz EJ, Jarczyk R, Jonderko G, Rubisz-Brezezinska J, Kucharz EJ, Jarczyk R, Jonderko G, Rubisz-Brezezinska J,
Brzezinska-Wcislo L. High serum level of prolactin in przezinska-Wcislo L. High serum level of prolactin in patient

18 Picco P, Gattorno M, Buoncompagni A, Facchetti P, Rossi $\mathrm{G}$, Pistoia V. Prolactin and interleukin 6 in prepubertal girls with juvenile chronic arthritis. J Rheumatol 1998;25:34751 .

19 Lavalle C, Loyo E, Paniagua R, Bermudez JA, Herrera J, Graef A, et al. Correlation study between prolactin and androgens in male patients with systemic lupus erythematosus. J Rheumatol 1987;14:268-72.

20 Jara LJ, Gomez-Sanchez C, Silveira LH, Martinez-Osuna P, Vasey FB, Espinoza LR. Hyperprolactinemia in systemic lupus erythematosus: association with disease activity. Am J Med Sci 1992;303:222-6.

21 Mok CC, Lau CS, Tam SC. Prolactin profile in a cohort of Chinese systemic lupus erythematosus patients. Br J Rheumatol 1997;36:986-9.

22 Huang CM, Chou CT. Hyperprolactinemia in systemic lupus erythematosus. Chung Hua I Hsueh Tsa Chih (Taipei) 1997;59:37-41

23 Jimena P, Aguirre MA, Lopez-Curbelo A, de Andres M, Garcia-Courtay C, Cuadrado MJ. Prolactin levels in patients with systemic lupus erythematosus: a case controlled study. Lupus 1998;7:383-6.

24 Neidhart M. Elevated serum prolactin or elevated prolactin/ cortisol ratio are associated with autoimmune processes in systemic lupus erythematosus and other connective tissue diseases. J Rheumatol 1996;23:476-81.

25 Pauzner R, Urowitz MB, Gladman DD, Gough JM. Prolactin in systemic lupus erythematosus. J Rheumatol 1994;21: 2064-7.

26 Buskila D, Lorber M, Neumann L, Flusser D, Shoenfeld Y. No correlation between prolactin levels and clinical activity in patients with systemic lupus erythematosus. J Rheumatol in patients with syster

27 Munoz JA, Gil A, Lopez-Dupla JM, Vazquez JJ, GonzalezGancedo P. Sex hormones in chronic systemic lupus erythematosus. Correlation with clinical and biological parameters. Ann Med Interne (Paris) 1994;145:459-63.

28 Ostendorf B, Fischer R, Santen R, Schmitz-Linneweber B, Specker C, Schneider M. Hyperprolactinemia in systemic lupus erythematosus? Scand J Rheumatol 1996;25:97102.

29 Miranda JM, Prieto RE, Paniagua R, Garcia G, Amato D, Barile L, et al. Clinical significance of serum and urine pro-
lactin levels in lupus glomerulonephritis. Lupus 1998;7: 387-91.

30 Alvarez-Nemegyei J, Cobarrubias-Cobos A, Escalante-Triay F, Sosa-Munoz J, Miranda JM, Jara LJ. Bromocriptine in systemic lupus erythematosus: a double-blind, randomized, placebo-controlled study. Lupus 1998;7:414-19.

31 McMurray RW, Weidensaul D, Allen SH, Walker SE. McMurray RW, Weidensaul D, Allen SH, Walker SE.
Efficacy of bromocriptine in an open label therapeutic trial for systemic lupus erythematosus. J Rheumatol 1995;22: 2084-91

32 Tan EM, Cohen AS, Fries JF, Masi AT, McShane DJ, Rothfield NF, et al. The 1982 revised criteria for the classification of systemic lupus erythematosus. Arthritis Rheum 1982;25:1271-7.

33 Vitali C, Bencivelli W, Isenberg DA, Smolen JS, Snaith ML, Sciuto $M$, et al. Disease activity in systemic lupus erythematosus: report of the Consensus Study Group of the European Workshop for Rheumatology Research. II. Identification of the variables indicative of disease activity and their use in the development of an activity score. The European Consensus Study Group for Disease Activity in European Consensus Study Group for Dis

34 Boyum A. Isolation of mononuclear cells and granulocytes from human blood. Isolation of monuclear cells by one 
centrifugation, and of granulocytes by combining centrifugation and sedimentation at 1 g. Scand J Clin Lab Invest gation and sedimentation

35 Fuh G, Cunningham BC, Fukunaga R, Nagata S, Goeddel DV, Wells JA. Rational design of potent antagonists to the human growth hormone receptor. Science 1992;256: $1677-80$

36 Rui H, Lebrun JJ, Kirken RA, Kelly PA, Farrar WL. JAK2 activation and cell proliferation induced by antibodymediated prolactin receptor dimerization. Endocrinology 1994;135:1299-306.

37 Mukherjee P, Mastro AM, Hymer WC. Prolactin induction of interleukin-2 receptors on rat splenic lymphocytes. Endocrinology 1990;126:88-94.

38 Rinkenberger JL, Wallin JJ, Johnson KW, Koshland ME. An interleukin-2 signal relieves BSAP (Pax5)-mediated repression of the immunoglobulin J chain gene. Immunity 1996; 5:377-86.

39 Walker AM, Montgomery DW, Saraiya S, Ho TW, Garewal $\mathrm{HS}$, Wilson J, et al. Prolactin-immunoglobulin G com- plexes from human serum act as costimulatory ligands causing proliferation of malignant $\mathrm{B}$ lymphocytes. Proc Natl Acad Sci USA 1995;92:3278-82.

40 Jackson RD, Wortsman J, Malarkey WB. Characterization of a large molecular weight prolactin in women with idiopathic hyperprolactinemia and normal menses. J Clin Endocrinol Metab 1985;61:258-64

41 Leanos A, Pascoe D, Fraga A, Blanco-Favela F. Antiprolactin autoantibodies in systemic lupus erythematosus patients with associated hyperprolactinemia. Lupus 1998; 7:398-403.

42 Leff MA, Buckley DJ, Krumenacker JS, Reed JC, Miyashita T, Buckley AR. Rapid modulation of the apoptosis regulatory genes, bcl-2 and bax by prolactin in rat $\mathrm{Nb} 2$ lymphoma cells. Endocrinology 1996;137:5456-62.

43 Fletcher-Chiappini SE, Compton MM, La Voie HA, Day EB, Witorsch RJ, Comptom MM. Glucocorticoidprolactin interactions in Nb2 lymphoma cells: antiprolifprolactin interactions in Nb2 lymphoma cells: antiprolif-
erative versus anticytolytic effects. Proc Soc Exp Biol Med erative versus anticyt 